\title{
Effect of Replacement of Soybean Meal with Duckweed (Lemna minor) Meal on the Growth Performance and Feed Utilization in Nile Tilapia Fingerlings
}

\author{
Ibrahim, W. M.; A. E. Eid; K. Mohamed" and B. Abd-elfattah \\ Department of Animal and Fish Resources, Faculty of Agriculture, Suez Canal University, Ismailia, Egypt.
}

Received: 13/8/2017

\begin{abstract}
The present study was designed to evaluate the use of Duckweed (Lemna minor) as are placement of soybean meal Protein for Nile tilapia (Oreochromis niloticus) fingerlings. Duckweed was incorporated into four isonitrogenous (30\% crude protein) and isocaloric diets (gross energy (448) Kcal/100g). The replacement levels were 25, 50, 75 and $100 \%$ of the soybean meal protein diet in addition to control diet. The experiment lasted for 56 days. The best final weight gain, specific growth rate, survival rate and feed utilization (FCR, FE and PER) were significantly $(p<0.05)$ higher for group of fish fed on diet replaced with 25\% Duckweed from Soybean protein diet. The highest feed conversion ratio was obtained for group of fish fed on diet replaced by $100 \%$ Duckweed. There was a significant difference $(\mathrm{p}<0.05)$ in protein and lipid in carcass proximate composition of the fish feed on diet replacement with $25 \%$ Duckweed from Soybean meal protein diet compared to those on the experimental groups. In conclusion, the study indicates that replacement soybean meal protein with $25 \%$ duckweed was the best in terms of growth performance and feed utilization.
\end{abstract}

Keywords: Duckweed (Lemna minor), replacement, growth performance, feed utilization, carcass composition Nile tilapia.

\section{INTRODUCTION}

The human demand of fish consumption is increased all over the world. Fish is about to become the main alternative source of animal protein. The culture trend of tilapia the exponential growth of the aquaculture sector during the past two decades is a result of the progressive intensification of production systems and use of quality feeds, which meet the nutritional requirements of cultured fish (FAO, 2012). Tilapia (Oreochromis niloticus), is widely cultured in the world. They tolerate a wide range of water quality conditions and could develop resistant to many diseases. Tilapia is a hardy prolific, fast growing tropical fish, and it can survive on a diversity of food (El-Sayed, 2006). Tilapia aquaculture represents about $42 \%$ of world total aquaculture fish production, and about $64 \%$ of the total fish production in Egypt (GAFRD, 2011). Demand and cost of fish feed and the global fishmeal price has increased more than two fold in recent years (FAO, 2013). One of the biggest problems facing the utilization of fish nutrition, in many aquaculture operations today, feed accounts more than half of the variable operating cost (NRC, 2011).

Therefore, the potential use of unconventional foodstuffs such as algae, for substitution the high cost ingredients such as fishmeal is very important. Algae have attention as a possible alternative protein source for cultured fish, particular in tropical and subtropical developing countries where algae production rates are high and their higher protein, vitamins and essential fatty acids contents (El-Hindawy et al., 2006). Duckweed (Lemna minor) is a cyanobacterium that has been commercially cultivated for more than 10 years due to its high nutritional content; e.g. protein, amino acids, vitamins, minerals, essential fatty acid and bcarotene (Mohedano, 2009).

Nowadays, Duckweed meal has been known for its high nutritive value with as much as $40 \%$ and above crude protein depending on the culture system (Hassan and Edward, 1992). Many studies have explored alternative dietary protein sources for tilapia culture (Nguyen et al., 2009; Zhao et al., 2009). Studies have been conducted on the use of aquatic plants in tilapia feeds (El-Sayed, 1994). Duckweeds are good food for tilapia, as it contains about $35 \%-45 \%$ crude protein, good amino acid balance, and mineral profile (Mbagwu and Adeniji, 1990). Mohedano et al. (2005) reported a reduction in feeding costs when replacing fishmeal with duckweed meal in tilapia diets. Tavares et al. (2008) showed that pelletized duckweed can represent up to $50 \%$ of a tilapia diet without affecting on weight gain of tilapia fingerlings.

The present study was aimed to investigate the effect of replacement soybean protein with different levels of duckweed $(0,25,50,75$ and $100 \%)$ on growth performance, feed utilization and economic analysis for monosex Nile tilapia fingerlings.

\section{MATERIALS AND METHODS}

The experiment was represented at El-Salam private fish hatchery, El Kantara, Ismailia- Egypt. The experiment aim to investigate, the effect of replacement of soybean meal by duckweed at levels of 25, 50, 75 and $100 \%$ in addition to control diet of monosex $(O$. niloticus) fingerlings.

\section{Water quality parameters}

Water temperature and dissolved oxygen were measured by mettle Toledo, model 128.s/No1242 respectively. Other water quality including $\mathrm{pH}$ and ammonia were measured every two days by $\mathrm{pH}$ meter (Orion model 720A, s/no 13062) and ammonia meter by Hanna ammonia meter. The averages of water quality parameters are presented in (Table 1).

\section{Experimental unit}

Fish were stocked in 15 hapa $(1.5 \mathrm{~m} \times 1.00 \mathrm{~m}$ $\times 1 . \mathrm{m})$ randomly divided into three equal experimental 
groups (50 fingerlings / replicate, three replicate hapas). The hapa were supplied all day with air blowers. Water temperature was maintained at $\left(28-25^{\circ} \mathrm{C}\right)$ inside green house. The part of water hapa was exchanged with fresh water $10 \%$ /day.

\section{Experimental fish}

Seven hundred and fifty fingerling monosex Nile tilapia ( $O$. niloticus) with average initial body weight of $4 \pm 0.1 \mathrm{~g}$ were obtained from El-Salam Fish Hatchery, Kantra, Ismailia governorate, Egypt. Fish were homogenous in body weights and apparently healthy. Fish were acclimated to farm conditions for 2 weeks' prior before the experiment study.

\section{Experimental diets}

Five isonitrogenous and isocaloric diets were formulated from practical ingredients (Table 2) where the control diet without duckweed and the other four diets were replacement of soybean meal protein with duckweed at levels 25, 50, 75 and 100\% respectively. The experimental diets were formulated to contain almost $30 \%$ crude protein and gross energy 444 $\mathrm{Kcal} / 100 \mathrm{~g}$. The experimental diets were prepared by individually weighing of each component thoroughly mixing the mineral, vitamins and additives with corn. This mixture was added to the components together with oil. Water was added until the mixture became suitable for making granules. The wet mixture was passed through CBM granule machine with powders. The produced were dried at room temperature then kept until experimental start. The composition and proximate analysis of the experimental diets are presented in Table (2). The fish were hand-fed at rate 5\% 4 times/day $(7,9$, 11,1 and $3 \mathrm{pm}$ ) throughout the experimental period 56 days.

Table (1): Water quality parameters

\begin{tabular}{lcccc}
\hline Experimental & Temperature & Dissolved Oxygen & Ammonia & pH \\
\hline Parameters & $28-25$ & $5.7-7 \mathrm{mg} / \mathrm{l}$ & $0.07-0.04 \mathrm{mg} / \mathrm{l}$ & $7.7-9$ \\
\hline
\end{tabular}

Table (2): Composition and proximate analysis of the experimental diets for Nile tilapia (Oreochromis niloticus) fingerlings fed diets supplemented with different levels of Duckweed from diet protein.

\begin{tabular}{|c|c|c|c|c|c|}
\hline \multirow{2}{*}{ Ingredients (Protein \%) } & \multicolumn{5}{|c|}{ Experimental Diets } \\
\hline & T1(Control) & T2 (25\%) & T3 (50\%) & T4 (75\%) & T5 (100\%) \\
\hline Fish meal $(70 \%)$ & 40 & 40 & 40 & 40 & 40 \\
\hline Duckweedmeal (38\%) & 0 & 112.5 & 225 & 337.5 & 450 \\
\hline Soybean meal (44\%) & 450 & 337.5 & 225 & 112.5 & 0 \\
\hline Corn gluten $(60 \%)$ & 70 & 70 & 70 & 70 & 70 \\
\hline Rice bran (12\%) & 100 & 100 & 100 & 100 & 100 \\
\hline Yellow corn $(8 \%)$ & 207 & 207 & 207 & 207 & 207 \\
\hline Wheat bran (13\%) & 100 & 100 & 100 & 100 & 100 \\
\hline Soybean oil & 30 & 30 & 30 & 30 & 30 \\
\hline $\mathbf{D C P}^{1}$ & 1 & 1 & 1 & 1 & 1 \\
\hline Vitamin\& Mineral Mix ${ }^{2}$ & 2 & 2 & 2 & 2 & 2 \\
\hline TOTAL & 1000 & 1000 & 1000 & 1000 & 1000 \\
\hline \multicolumn{6}{|c|}{ Chemical Composition (\%) } \\
\hline Dry matter & 89.95 & 89.94 & 70.69 & 61.06 & 50.31 \\
\hline Crude protein & 30.36 & 29.9 & 29.4 & 30.1 & 30.00 \\
\hline Ether extract & 7.65 & 8.42 & 8.8 & 10.10 & 10.75 \\
\hline Crude fiber & 6.52 & 5.7 & 6.1 & 6.8 & 7.1 \\
\hline Ash & 5.32 & 6.76 & 7.20 & 8.61 & 8.9 \\
\hline N.F. $\mathbf{E}^{3}$ & 51.15 & 49.22 & 48.5 & 44.39 & 43.25 \\
\hline $\begin{array}{l}\text { Gross energy Kcal/ } \\
\operatorname{100g}^{4}\end{array}$ & 444.9 & 445.4 & 443.5 & 442.77 & 443.6 \\
\hline$\underset{\mathrm{mg} / \mathrm{kcal}}{\mathrm{P} / \mathrm{E} \text { ratio CP/GE kcal }}$ & 66.13 & 67.13 & 66.29 & 67.98 & 67.92 \\
\hline \multicolumn{3}{|c|}{$\begin{array}{l}\text { 1)DCP (Di calcium phosphate) } \\
\text { 2) Each Kg vitamin \& mineral mixture premix contained } \\
\text { Vitamin A, } 4.8 \text { million IU, D3, } 0.8 \text { million IU; E, } 4 \mathrm{~g} \text {; K, } \\
0.8 \mathrm{~g} \text {; B1, } 0.4 \mathrm{~g} \text {; Riboflavin, } 1.6 \mathrm{~g} \text {; B6, } 0.6 \mathrm{~g} \text {, B12, } 4 \mathrm{mg} \text {; } \\
\text { Pantothenic acid, } 4 \mathrm{~g} \text {; Nicotinic acid, } 8 \mathrm{~g} \text {; Folic acid, } 0.4 \\
\text { g Biotin, } 20 \mathrm{mg}, \mathrm{Mn}, 22 \mathrm{~g} \text {; Zn, } 22 \mathrm{~g} \text {; Fe, } 12 \mathrm{~g} \text {; Cu, } 4 \mathrm{~g} \text {; I, } \\
0.4 \mathrm{~g} \text {, Selenium, } 0.4 \mathrm{~g} \text { and Co, } 4.8 \mathrm{mg} \text {. }\end{array}$} & \multicolumn{3}{|c|}{$\begin{array}{l}\text { 3) Nitrogen Free Extract }=100-(\% \text { Protein }+\% \text { Fat }+ \\
\% \text { Fiber }+\% \text { Ash }) \text {. } \\
\text { 4) Gross Energy based on protein }(5.65 \mathrm{Kcal} / \mathrm{g}) \text {, fat }(9.45 \\
\text { Kcal } / \mathrm{g}) \text { and carbohydrate }(4.11 \mathrm{Kcal} / \mathrm{g}) \text {. According to } \\
(\mathrm{NRC}, 2011) \text {. } \\
\text { 5) Protein Energy Ratio. ( crud protein } / \mathrm{GE} \mathrm{Kcal}) \text {. } \\
\text { According to (NRC, 2011) }\end{array}$} \\
\hline
\end{tabular}




\section{Experimental Methodology}

\section{Fish samples}

At the start and the end of the main experimental period (56 day), 5 fish were randomly taken from each experimental group. Fish were used for chemical analysis of the whole body. The tested diets and body were analyzed for crud protein (CP \%) ether extract (EE \%), crude fiber (CF \%), ash (\%) and moisture. The whole body composition of fish samples were analyzed except crud fiber ( $\mathrm{CF} \%$ ) according to the procedures described by standard (A O A C). The nitrogen free-extract (NFE \%) was calculated by differences.

\section{Growth performance parameters}

The growth performance and feed utilization parameters are calculated according to the follow:

Average Weight Gain (AWG)

$(A W G)=$ Average final weight $(g)-$ Average initial weight $(\mathrm{g})$

Average Daily Gain (ADG)

$(\mathrm{ADG})=[$ Average final weight $(\mathrm{g})-$ Average initial weight $(\mathrm{g})]$ / time (days)

Specific Growth Rate (SGR \%/day)

$(\mathrm{SGR} \% /$ day $)=100[\mathrm{Ln} \mathrm{Wt} 1-\mathrm{Ln} \mathrm{Wt} .0 / \mathrm{t}]$

Where: - Ln: normal log, Wt. 0: initial weight (g)

Wt. 1: final weight $(\mathrm{g}) \quad \mathrm{T}$ : time of days

\section{Feed and protein utilization parameters}

Feed and protein utilization parameters are calculated according to the following equations:

Conversion Ratio (FCR)

$\mathrm{FCR}=$ Total feed consumption/weight gain .

Feed Efficiency $(\mathrm{FE})=$ weight gain/Total feed consumption

Protein Efficiency Ratio $($ PER) = weight gain/protein consumed

Survival (\%):

$\mathrm{SR}=\mathrm{Ni} \times 100 / \mathrm{N} 0$

Where: $\mathrm{Nt}=$ Total number of fish survived in tank at end of experiment

$\mathrm{N} 0=$ Total number of fish survived in tank at beginning of experiment

\section{Statistical analysis}

The data obtained in this study were analyzed by one-way ANOVA procedure of Statistical Analysis System (SAS Institute, 1998). Means were compared by Duncan's new multiple ranges test (Duncan, 1955).

$$
\text { Where: } Y \mathbf{i j}=\boldsymbol{\mu}+\mathrm{Di}+\mathbf{e i j}
$$

$\mathrm{Yij}=$ the observation of the $\mathrm{j}$ th individual from $\mathrm{D}$ th Diet

$\mu=$ the overall mean.

$\mathrm{Di}=$ The Fixed effect of the D th Diet

eij $=$ The random error associated with the individual $\mathrm{j}$

\section{Economical evaluation}

The cost of feed to raise unit biomass of fish was estimated by a simple economic analysis. The estimation was based on local retail sale market price of all the dietary ingredients at the time of the study.

Cost $/ \mathrm{kg} \operatorname{diet}(\mathrm{LE})=$ Cost per $\mathrm{Kg} \operatorname{diet} \mathrm{L} . \mathrm{E}$

Consumed feed to produce $1 \mathrm{~kg}$ fish $(\mathrm{kg})=$ Feed intake per fish per period/ final weight per fish $\mathrm{Kg} / \mathrm{Kg}$

Feed cost per kg fresh fish (LE) = Step $1 \times$ step 2

Relative $\%$ of feed cost $/ \mathrm{kg}$ fish $=$ Respective figures for step 3/highest figure in this step

Feed cost $/ \mathrm{Kg}$ gain $(\mathrm{LE})=$ Feed intake per $\mathrm{Kg}$ gain $\times$ step 1 Relative \% of feed cost of $\mathrm{Kg}$ gain $=$ Respective figures for step 5/highest figure in this step

\section{RESULTS AND DISCUSSION}

\section{Growth Performance}

The effects of Duckweed supplementation on growth performance and feed utilization of monosex Nile Tilapia (Oreochromis niloticus) fingerlings fed tested diets is presented in Table (3). No significant differences $(\mathrm{P}<0.05)$ in initial body weight were found among the different experimental treatments, indicating the accuracy of randomization process between the experimental treatments. It was observed that groups of fish fed the diet containing Duckweed $25 \%$ showed highest values of body weight, weight gain, relative growth rate (RGR.), specific growth (SGR) and the lowest body weight, weight gain, relative growth rate (RGR.), specific growth were obtained in group of fish on T4 and T5 (75 and 100\% replacement of soybean meal protein with duckweed meal. In agreement with Fasakin et al. (1999). They stated that increase in dietary duckweed inclusion resulted in progressively reduced growth performance and nutrients utilization of fish. Ahamad et al. (2003) reported also the replacement of sesame oil cake by duckweed in broiler diet. They stated that partial replacement of the costly oil seed by cheaper unconventional duckweed in broiler diet resulted in increased profitability. The protein efficiency ratio in the diets at 10 to $20 \%$ inclusive levels of duckweed meal in the experimental diet showed no significant difference compared with the control diet. Close results was obtained by Bairagi et al. (2002) reported that $30 \%$ fermented lemna leaf meal incorporated in the diet of Labeo rohita gave the best performance in terms of growth response, food conversion ratio and protein efficiency. Yilmaz et al. (2005) reported no significant difference between the growth performance of fish that were fed diets containing up to $20 \%$ duckweed and fish that were fed the control diet.

Feed intake (FI) and Protein Efficiency Ratio (PER) was significantly highest $(\mathrm{P}<0.05)$ in $25 \%$ replacement of soybean protein with duckweed protein (Table 3). In agreement with Fasakin et al. (1999) they reported that there was no significant difference in $(\mathrm{P}<0.05)$ in nutrient utilization of fish fed on diets containing up to $20 \%$ duckweed inclusion and the control. They however, stated that increase in dietary duckweed inclusion resulted in progressively reduced growth performance and nutrients utilization of fish. This report is similar to the findings of this study. 
Inclusion of duckweed meal in the diet of other animals to replace fishmeal or soybean has also been reported by Samnang (1999), and Becerra et al. (1995) and Yilmaz et al. (2005). At the end of the experiment the group of fish on $\mathrm{T} 1, \mathrm{~T} 2$ had a significantly highest $(\mathrm{P}<0.05) \mathrm{PER}$ and FI than the rest of experimental groups T3, T4 and T5. The lowest FCR was obtained in group of fish on $\mathrm{T} 1$ and T2 and the highest FCR was found in group of fish on T4 and T5. In agreement with Becerra et al.
(1995) and Samnang (1999), Moreover, Bairagi et al. (2002) reported that 30\% fermented lemna leaf meal incorporated in the diet of Labeo rohita gave the best performance in terms of feed conversion ratio and protein efficiency. In agreement with Bairagi et al. (2002) reported that $30 \%$ fermented lemna leaf meal incorporated in the diet of Labeo rohita gave the best performance in terms of growth response, food conversion ratio and protein efficiency.

Table (3): Effect of replacement of soybean meal with duckweed on growth performance and feed utilization of fingerlings ( $\mathrm{g}$ Mean $\pm \mathrm{SE}$ ) of monosex Nile tilapia (O. niloticus) throughout the experimental period (56 days)

\begin{tabular}{|c|c|c|c|c|c|}
\hline \multirow{2}{*}{ Items } & \multicolumn{5}{|c|}{ Duckweed levels (\%) } \\
\hline & Control T (1) & $\mathrm{T}(2)$ & $\mathrm{T}(3)$ & $\mathrm{T}(4)$ & $\mathbf{T}(5)$ \\
\hline Average Initial weight (g) & 4. $1 \pm 0.1$ & $4.20^{\mathrm{a}} \pm 0.01$ & $4.2 \pm 0.01$ & $4.11 \pm 0.01$ & $4.20 \pm 0.14$ \\
\hline Average Final weight (g). & $28.70^{\mathrm{a}} \pm 0.08$ & $28.50^{\mathrm{a}} \pm 0.7$ & $22^{b} \pm 0.3$ & $19.21^{\mathrm{c}} \pm 0.7$ & $17.41 \pm 0.4$ \\
\hline Average Weight gain (g) & $24.50^{\mathrm{a}} \pm 0.13$ & $24.30^{\mathrm{a}} \pm 0.13$ & $18.6^{\mathrm{b}} \pm 0.13$ & $16.69^{\mathrm{c}} \pm 0.14$ & $14.1 \pm 0.14$ \\
\hline $\begin{array}{l}\text { Specific Growth Rate } \\
\text { (SGR) (\%/day) }\end{array}$ & $3.48^{\mathrm{a}} \pm 0.13$ & $3.41^{\mathrm{a}} \pm 0.13$ & $2.95^{\mathrm{b}} \pm 0.13$ & $2.76^{\mathrm{c}} \pm 0.14$ & $2.54 \pm 0.14$ \\
\hline Feed Intake (FI) (g) & $47.99^{\mathrm{a}} \pm 0.13$ & $49.44^{\mathrm{a}} \pm 0.13$ & $43.3^{b} \pm 0.13$ & $44.27^{\mathrm{c}} \pm 0.14$ & $41.14 \pm 0.14$ \\
\hline $\begin{array}{l}\text { Feed Conversion Ratio } \\
\text { (FCR) }\end{array}$ & $1.95^{\mathrm{a}} \pm 0.13$ & $2.03^{\mathrm{a}} \pm 0.13$ & $2.32^{\mathrm{b}} \pm 0.13$ & $2.7^{\mathrm{c}} \pm 0.14$ & $2.9 \pm 0.14$ \\
\hline $\begin{array}{l}\text { Protein efficiency Ratio } \\
\text { (PER) }\end{array}$ & $1.70^{\mathrm{a}} \pm 0.13$ & $1.60^{\mathrm{a}} \pm 0.13$ & $1.40^{\mathrm{b}} \pm 0.13$ & $1.20^{\mathrm{c}} \pm 0.14$ & $1.10 \pm 0.14$ \\
\hline Feed Efficiency (FE) & $0.51^{\mathrm{a}} \pm 0.01$ & $0.49^{\mathrm{a}} \pm 0.01$ & $0.43^{b} \pm 0.01$ & $0.38^{\mathrm{c}} \pm 0.01$ & $0.34 \pm 0.14$ \\
\hline Survival Rate (\%) & $97^{\mathrm{a}} \pm 0.13$ & $97^{\mathrm{a}} \pm 0.13$ & $93^{c} \pm 0.13$ & $94^{b} \pm 0.13$ & $93^{c} \pm 0.13$ \\
\hline
\end{tabular}

Means \pm SE in the same letter in the same row is not significantly different at $\mathrm{P}<0.05$.

\section{Carcass composition of fish}

Table (4) shows the effect of replacement of soybean meal protein by duckweed at different levels on body composition for 56 days. Duckweed was significantly $(\mathrm{P}<0.05)$ affected whole-fish body composition (Table 4). Fish fed with the control diet had the lowest protein content; however, all diets contained with duckweed appeared to improved protein content. Carcass lipid and protein content was also affected by dietary treatments with the highest values in (T1) and (T2), which were statistically $(\mathrm{P}<0.05)$ highest than the rest of dietary treatments. On the other hand, changes in protein and lipids contents in fish body could be linked with changes in their synthesis, deposition rate in muscle and/or different growth rat (Yilmaz et al., 2005).

Table (4): Effect of replacement of soybean meal protein with duckweed on body composition of monosex Nile tilapia (O. niloticus) fingerlings on dry matter basis

\begin{tabular}{lcccc}
\hline $\begin{array}{l}\text { Chemical } \\
\text { composition }\end{array}$ & Dry matter (\%) & Crude protein (\%) & Ether extract (\%) & Ash (\%) \\
\hline Initial & $73.40 \pm 0.27$ & $61.20 \pm 0.27$ & $22.80 \pm 0.27$ & $12.60 \pm 0.27$ \\
Control T1 & $72.50 \pm 0.27$ & $63.70 \pm 0.41^{\mathrm{a}}$ & $23.80 \pm 0.18^{\mathrm{a}}$ & $12.50 \pm 0.13^{\mathrm{a}}$ \\
T2 & $72.50 \pm 0.22$ & $64.80 \pm 0.51^{\mathrm{a}}$ & $24.70 \pm 0.12^{\mathrm{a}}$ & $12.90 \pm 0.23^{\mathrm{a}}$ \\
T3 & $72.50 \pm 0.25$ & $63.30 \pm 0.21^{\mathrm{b}}$ & $22.80 \pm 0.14^{\mathrm{b}}$ & $12.10 \pm 0.22^{\mathrm{a}}$ \\
T4 & $72.50 \pm 0.22$ & $62.60 \pm 0.40^{\mathrm{c}}$ & $22.10 \pm 0.16^{\mathrm{c}}$ & $12.10 \pm 0.20^{\mathrm{a}}$ \\
T5 & $72.50 \pm 0.24$ & $62.20 \pm 0.32^{\mathrm{c}}$ & $25.10 \pm 0.18 \mathrm{c}$ & $12.40 \pm 0.22 \mathrm{a}$ \\
\hline
\end{tabular}

Note: Values are means $\pm \mathrm{SE}$ of three replications. Means in the same column having different superscripts are significantly different $(\mathrm{P}<0.05)$. 


\section{Economical evaluation}

Calculations of economic efficiency of the tested diets based on the cost of feed, costs of one $\mathrm{Kg}$ gain in weight and its ratio with the control group are shown in Table 5. The highest Feed cost $/ 1 \mathrm{Kg}$ fresh fish gain (3.25 LE) for T1 followed by 2.94 L.E for T2, 2.14 LE for T3. 1.92 L.E for T4 and 1.44L.E for T5 respectively.

Feed cost / Kg gain were 13.20, 12.08, 11.48, 11.72 and 10.12 For T1, T2, T4, T4 and T5 respectively and Relative $\%$ of feed cost of $\mathrm{Kg}$ gain (87\%) in group of fish fed diet 2 (25\% Duck weeds).This indicates that T5 was the most economic than the rest of experimental groups. These results indicates that replacement of soybean meal protein with duckweed at level 100\% were the most economic in term of economical point of view. Moreover 25\% replacement soybean meal protein with duckweed was the best in terms of nutritional point of view.

\section{CONCLUSION}

In conclusion, it would be advisable to include up to $25 \%$ duckweed in commercial feed for $(O$. niloticus) fingerlings in order to produce results similar to those obtained with the control diet with respect to growth, feed utilization, and body composition. These findings also support the use of duckweed in commercial grow-out carp feeds as a dry ingredient. Duckweed meal should be considered for both cold and warm water fish nutrition.

Table (5): Economic analysis of Nile tilapia fingerlings (O. niloticus) fed different levels of Duckweed for 56 gains (L.E)

\begin{tabular}{|c|c|c|c|c|c|}
\hline \multirow{2}{*}{ Components } & \multicolumn{5}{|c|}{ Treatments } \\
\hline & Control T(1) & $\mathrm{T}(2)$ & $\mathbf{T}(3)$ & $\mathrm{T}(4)$ & $\mathbf{T}(5)$ \\
\hline Cost/1 Kg/diet & 6.77 & 5.95 & 4.95 & 4.34 & 3.49 \\
\hline (FI)2 & 47.99 & 49.44 & 43.3 & 44.27 & 41.14 \\
\hline $\begin{array}{l}\text { Feed cost per kg fresh } \\
\text { fish (LE) } 3\end{array}$ & 3.25 & 2.94 & 2.14 & 1.92 & 1.438 \\
\hline $\begin{array}{l}\text { Relative \% of feed } \\
\text { cost/kg fish4 }\end{array}$ & 100 & 90.46 & 65.84 & 59.07 & 44.24 \\
\hline (FCR)5 & 1.95 & 2.03 & 2.32 & 2.70 & 2.90 \\
\hline $\begin{array}{l}\text { Feed cost } / 1 \mathrm{Kg} \text { gain } \\
\text { (LE6 }\end{array}$ & 13.20 & 12.08 & 11.48 & 11.72 & 10.12 \\
\hline
\end{tabular}

\footnotetext{
$1-\mathrm{Cost} / \mathrm{Kg} / \mathrm{diet}$

2- Feed Intake

3- Feed cost per/ $\mathrm{kg} /$ fresh fish $(\mathrm{LE})=\mathrm{Cost} / \mathrm{Kg} / \mathrm{diet} \mathbf{x}(\mathrm{FI}) / 100$

4- Relative $\%$ of feed cost $/ \mathrm{kg}$ fish

5- Feed Conversion Ratio

6- Feed cost $/ 1 \mathrm{Kg}$ gain $(\mathrm{LE})=(\mathrm{FCR}) \times$ Cost.
}

\section{REFERENCES}

A.O. A. C. methods (1995) AOAC. (Association of Official Analytical Chemists), Official Methods of Analysis. Washington DC.

Ahamad, M. U., M. R. S. Swapon, T. U. Yeasmin, M. S., Raham and M. S. Ali (2003). Replacement of sesame oil cake by Duckweed (Lemna minor) in broiler diet. Pakistan Journal of Biological Science, 6(16): 1450-1453.

Bairagi. A., K. Ghosh, S. K. Sen and A. K. Ray (2002). Enzyme producing bacterial flora isolated from fish digestive tracts. Aquaculture International, 10: 109-121.

Becerra, M, T. R. Preston and R. B. Ogle (1995). Effect of replacing whole boiled soya beans with azolla in the diets of growing ducks. Livestock Research for Rural Development, 7(3): http://www.cipav.org.co/lrrd/lrrd7/3/7.htm.

Boyd, C. E. (1984). Water quality in warm water fishponds. Auburn University Agriculture Experimental Station.
Duncan, D. B. (1955). Multiple ranges and multiple Ftest. Biometrics, 1-42.

El-Hindawy, M. M., M. A. Abd-Razic, H. A. Gaber and M. M. Zenhom (2006). Effect of various levels of dietary algae Scenedesmus spp. on physiological performance and digestibility of Nile tilapia fingerlings. $1^{\text {st }}$ Scientific Conference of the Egyptian Aquaculture Society. Sharm ElSheikh-Sinai, Egypt, pp 137-149.

El-Sayed, A. F. M. (2006). Tilapia Culture. CABI publishing, CABI International Willingford, Oxford shire, UK.

.El-Sayed, A-F.M. (1994). Evaluation of soybean meal, Spirulina alga meal and chicken offal meal as protein sources for silver seabream. Aquaculture, 127: 169-176.

FAO (2012). Cultured Aquatic Species Information Programme. (Oreochromis niloticus). Cultured Aquatic Species Information Programme. Text by Rakocy, J. E. In: FAO Fisheries and Aquaculture Department [online]. Rome. 
Updated 18 February 2005. [Cited 11 September 2012].

FAO (2013). Despite the increase in fish feed prices, the farm gate prices of aquaculture products.

GAFRD (2011). Book of Fishery Statistics. General Authority for Fish Resource Development, Cairo, Egypt.

Hassan, M. S. and P. Edwards (1992). Evaluation of duckweed (Lemna perpusilla and Spirodela polyrhiza) as feed for Nile Tilapia (Oreochromis niloticus). Aquaculture, 104: 315-326.

Mohedano, M. L., K. Overweg, A. de la Fuente, M. Reuter, S. Altabe, F. Mulholland, D. de Mendoza, P. Lopez and J. M. Wells (2005). J. Bacteriol., 187: 2357-2367. [PMC free article] [PubMed].

Mbagwu, I.G., F.C. Okoye and H.A. Adiniji (1990). Studies on the use duckweed (Lemna paucicostata Hegelm.) as fish food, Tech. Rep. Ser. Natl. Freshwater Fish. Resh. Nigeria, Bussa, Nigeria, No.22, 25 pp.

NRC (2011). (National Research Council). Nutrient requirements of fish. Committee on Animal Nutrition Board on Agriculture. National Academy Press, Washington D. C, USA. p. 114.

Nguyen, W. K., K. Chik-Boon, S. Kumar and A. SitiZahrah (2009). Effects of dietary organic acids on growth, nutrient digestibility and gut microflora of red hybrid tilapia, Oreochromis sp., and subsequent survival during a challenge test with Streptococcus agalactiae. Aquaculture Research, 40: 1490-1500.

Rusoff, L. L., E. W. Blakney and D. D. Culley (1980). Duckweeds (Lemnacae Family): A Potential Source of Protein and Amino Acids. J. Agric. Food Chem., 28: 848-50.
Said, M. Z. M., D. D. Jr. Culley, L. C. Standifer, E. A. Epps, R. W. Myers and S. A. Boney (1979). Effect of harvest rate waste loading, and stocking density on the yield of duckweeds. Proceedings of the World Mariculture Society, 10: 769-780.

S. A. S. Statistical Analysis Systems (1998). SAS program Ver. 6. 12, SAS institute incorporation. Cary. NC 27513 USA.

Samnang, H. (1999). Duckweed versus ground soya bean as supplements for scavenging native chickens in an integrated farming system. Livestock Research For Rural Development, 11(1): http://www.cipav.org.co//rrd//rr11/1/sa $\mathrm{m} 111 . \mathrm{htm}$

Thodesen, J., M. Rye, Y. Wong, K. Yang, H. Benston and T. Giedrem (2012). Genetic improvement of tilapias in China: genetic parameters and selection responses in growth of Nile tilapia (Oreochromis niloticus) after six generations of multi-trait selection for growth and fillet yield. Aquaculture, 366-367: 67-75.

Tavares, F. de A., J. S. R. Roudrigues, D. M. Fracalossi, J. Esquivel and R. Roubach (2008). Dried duckweed and commercial feed promote adequate growth performance of tilapia fingerlings. Biotemas, 21(3): 91-97

Yilmaz, D, B. Ersoy, E. Bilgin, G. Gümüşer, E. Onur ans E.D. Pinar (2005). Bone mineral density in girls and boys at different pubertal stages: relation with gonadal steroids, bone formation markers, and growth parameters. J. Bone Miner Metab., 23(6): 476-82.

Zhou, Z., Y. Liu, S. He, P. Shi, X. Gao, B. Yao and E. Ringø (2009). Effects of dietary potassium diformate (KDF) on growth performance, feed conversion and intestinal bacterial community of hybrid tilapia (O. reochromis niloticus $\times O$. aureus). Aquaculture, 291: 89-94.

\footnotetext{
تأثير إحلال كسب فول الصويا بمسحوق عدس الماء علي أداء النمو والإستفاده الغذائية لإصبعيات سمك البلطي النيلي

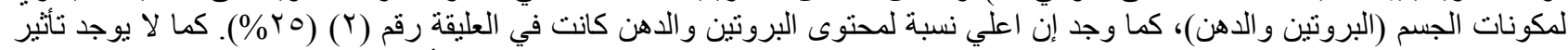

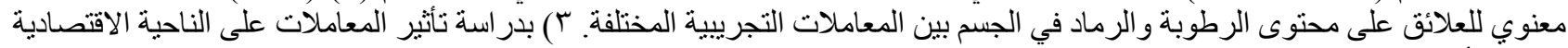

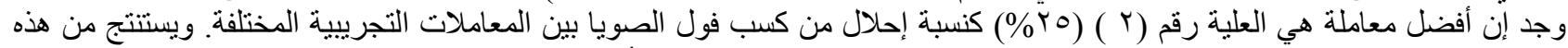

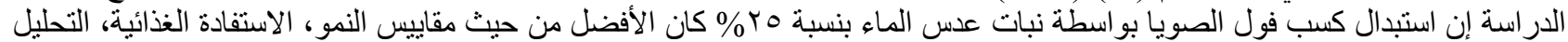

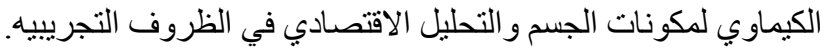

